\title{
Effects of Increasing Milking Frequency During the Last 28 Days of Gestation on Milk Production, Dry Matter Intake, and Energy Balance in Dairy Cows
}

\author{
R. R. Rastani, ${ }^{* 1}$ N. Silva del Rio, ${ }^{*}$ T. F. Gressley, $\dagger^{2}$ G. E. Dahl, $\dagger^{3}$ and R. R. Grummer ${ }^{\star 4}$ \\ ${ }^{*}$ Department of Dairy Science, University of Wisconsin, Madison 53706 \\ †Department of Animal Sciences, University of Illinois, Urbana 61801
}

\section{ABSTRACT}

Forty-eight Holstein cows were used in a randomized block design to evaluate different dry period lengths and prepartum milking frequencies (MF) on subsequent milk production, milk composition, solids-corrected milk production, dry matter intake (DMI), and energy balance. Lactating cows, milked 2 times/d, began a 7-d covariate period $35 \mathrm{~d}$ prior to the expected calving date. Cows were

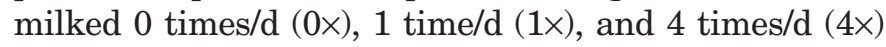
for the last $28 \mathrm{~d}$ of gestation. If milk production decreased to less than $0.5 \mathrm{~kg} / \mathrm{milking}$ or $1 \mathrm{~kg} / \mathrm{d}$, milking via machine ceased; however, teat stimulation continued 1 or 4 times/ $\mathrm{d}$ according to the treatment assignment. All cows were milked 2 times/d postpartum (wk 1 to 10). Prepartum DMI tended to be greater for $1 \times$ and $4 \times$ compared with $0 \times$. Prepartum, cows milked $1 \times$ produced $17 \%$ less milk than cows milked $4 \times(5.9$ and $7.1 \mathrm{~kg} / \mathrm{d}$, respectively). There were no differences in prepartum and postpartum body condition scores, body weights, and DMI. Postpartum milk production by cows following their third or greater gestation was greater for $0 \times$ and $4 \times$ compared with $1 \times$. Postpartum milk production by cows following their second gestation was significantly decreased with increased MF ( $0 \times$ vs. $1 \times$ and $4 \times$ ). Regardless of parity, postpartum solids-corrected milk was greater for $0 \times$ compared with $1 \times$ and $4 \times$. Postpartum fat yield was greater for $0 \times$ vs. $4 \times$, with $1 \times$ being intermediate. Postpartum protein yield was greater for $0 \times$ vs. $4 \times$, whereas $0 \times$ tended to have greater protein yield than $1 \times$. Postpartum energy balance was greater for $1 \times$ and $4 \times$ relative to $0 \times$. Continuous milking $(1 \times$ and $4 \times)$ resulted in a loss of milk production in the subsequent lactation for cows following their

\footnotetext{
Received July 26, 2006.

Accepted November 2, 2006.

${ }^{1}$ Current address: MSC Specialty Nutrition, Dundee, IL 60118.

${ }^{2}$ Current address: University of Delaware, Department of Animal and Food Sciences, Newark, DE 19716.

${ }^{3}$ Current address: University of Florida, Department of Animal Sciences, Gainesville, FL 32611.

${ }^{4}$ Corresponding author: rgrummer@facstaff.wisc.edu
}

second gestation; however, for cows following their third or greater gestation, increasing the MF from $1 \times$ to $4 \times$ in the last $28 \mathrm{~d}$ of gestation alleviated the loss in milk production.

Key words: continuous milking, energy balance, milking frequency, transition period

\section{INTRODUCTION}

The benefits derived from continuous milking are greater energy balance (EB) postpartum, reduced postpartum plasma NEFA concentrations, reduced postpartum liver triglyceride concentrations (Rastani et al., 2005), and earlier first postpartum ovulation (Gümen et al., 2005). However, a 12 to $25 \%$ loss in milk production in the subsequent lactation has consistently been reported in cows that were continuously milked compared with cows given a 56- to 60-d dry period (DP) without supplemental bST (Swanson, 1965; Smith et al., 1967; Remond et al., 1992, 1997; Annen et al., 2004a; Rastani et al., 2005). A recent experiment (Annen et al., 2004a) indicated no loss of milk production in cows that were continuously milked in their third or greater gestation, when bST was given either according to label instructions (no bST between parturition and 63 DIM) or continuously (off-label; bST given in late gestation and early lactation), compared with milk production in cows with a 60-d DP that received bST according to label instructions. Annen et al. (2004b) randomly assigned cows in their second gestation to a control or bST treatment (bST given continuously from late gestation through early lactation) and used the half-udder model to impose a 60-d DP or continuous milking. Continuous milking reduced milk production by $52 \%$ for the first $30 \mathrm{~d}$ postpartum; however, bST administration did not alleviate the decline. These results suggest that it is possible to achieve similar milk production in cows that are milked continuously during their third or greater gestation relative to those with a 60 -d DP. However, whether it is possible to achieve these results without the use of bST prepartum is unclear. 
If continuous milking is to become a viable management practice, it is necessary to find ways to reduce the loss in postpartum milk production. Increasing milking frequency (MF) during lactation is known to result in increased milk production (Pearson et al., 1979; Poole, 1982; DePeters et al., 1985; Hillerton et al., 1990). Furthermore, increasing MF in early lactation results in greater milk production for the entire lactation (BarPeled et al., 1995; Hale et al., 2003; Dahl et al., 2004b). Increasing $\mathrm{MF}$ also results in increased mammary gland DNA synthesis in cows (Hillerton et al., 1990) and goats (Wilde et al., 1987; Boutinaud et al., 2003), as well as increased mammary gland RNA synthesis in goats (Wilde et al., 1987; Boutinaud et al., 2003). Thus, increasing MF prepartum may prevent cell loss and maintain cell activity in the mammary gland. Additionally, increasing MF results in reduced concentrations and activities of plasmin and plasminogen (Stelwagen et al., 1994; Kelly et al., 1998; Sorensen et al., 2001), which are associated with gradual involution of the mammary gland in dairy cows (Politis et al., 1989; Politis et al., 1990).

Increasing $\mathrm{MF}$ is associated with an increased prolactin (PRL) concentration (Bar-Peled et al., 1995; Dahl et al., 2004a) and increased expression of prolactin receptor (PRL-R; Dahl et al., 2002). Cows that are milked more frequently may be more sensitive to PRL, which is key to the differentiation of mammary epithelial cells. This management practice may prevent the decrease in milk production experienced by continuously milked cows (i.e., cows with no DP) in the subsequent lactation.

The objective of this experiment was to evaluate different DP lengths and prepartum MF on subsequent milk production, DMI, and EB. We hypothesized that increasing MF in the last $28 \mathrm{~d}$ of gestation would increase the PRL concentration and PRL-R expression, leading to greater mammary gland differentiation, and would improve milk production in the subsequent lactation in cows that were milked continuously relative to those that were not milked.

\section{MATERIALS AND METHODS}

\section{Cows and Treatments}

Forty-eight Holstein cows (30 second gestation, and 18 third or greater gestation) were selected from the university dairy herd for this experiment. All cows had to fulfill the following selection criteria: 1 ) carrying a single fetus, 2) less than 400 DIM at $60 \mathrm{~d}$ prior to expected calving date (ECD) or have a BCS $<4.0$ if over $400 \mathrm{DIM}, 3)$ producing at least $15 \mathrm{~kg}$ of milk/d at $60 \mathrm{~d}$ prior to ECD, and (4) producing at least $10 \mathrm{~kg}$ of milk/ $\mathrm{d}$ at $35 \mathrm{~d}$ prior to ECD. In addition, if cows were receiving bST, it was ceased before $120 \mathrm{~d}$ prior to ECD. From 60 $\mathrm{d}$ prior to ECD through $29 \mathrm{~d}$ prior to ECD, all cows were
Table 1. Ingredient composition of diets

\begin{tabular}{|c|c|c|}
\hline Ingredient & Prepartum & Postpartum \\
\hline & - & \\
\hline Corn silage & 42.0 & 31.5 \\
\hline Alfalfa silage & 15.0 & 15.5 \\
\hline Ground corn & 18.0 & 26.8 \\
\hline Straw & 10.0 & 0.0 \\
\hline Cottonseed, whole linted & 4.0 & 9.0 \\
\hline Roasted soybeans, whole & 3.0 & 7.8 \\
\hline Soybean meal $(48 \%)$ & 4.0 & 2.8 \\
\hline Corn gluten meal & 2.0 & 3.3 \\
\hline Blood meal & 0.5 & 0.8 \\
\hline Trace-mineralized salt ${ }^{1}$ & 0.5 & 0.6 \\
\hline Dicalcium phosphate & 0.2 & 0.4 \\
\hline Calcium carbonate & 0.3 & 0.4 \\
\hline Vitamin $\operatorname{mix}^{2}$ & 0.3 & 0.3 \\
\hline Magnesium oxide & 0.2 & 0.2 \\
\hline Sodium bicarbonate & 0.0 & 0.6 \\
\hline
\end{tabular}

${ }^{1}$ Contains $0.55 \% \mathrm{Mn}, 0.55 \% \mathrm{Zn}, 0.35 \% \mathrm{Fe}, 0.14 \% \mathrm{Cu}, 0.008 \% \mathrm{I}$, $0.006 \%$ Se, and $0.002 \%$ Co.

${ }^{2}$ Contains 3,304 IU/g of DM of vitamin A, 1,101 IU/g of DM of vitamin $\mathrm{D}$, and $55 \mathrm{IU} / \mathrm{g}$ of $\mathrm{DM}$ of vitamin $\mathrm{E}$.

milked 2 times/d. From 35 to 29 d prior to ECD, cows were fed the same diet (Table 1). Additionally, DMI and milk production were measured daily, milk composition and SCS were measured at 4 consecutive milkings (i.e., 2 consecutive days), and BW and BCS were measured once during the covariate week; the weekly averages for the previously mentioned variables were used as covariate measurements. The University of Wisconsin, College of Agriculture and Life Sciences, Animal Care and Use Committee approved all procedures.

Cows were blocked by parity (second or third and greater gestation) and average daily milk production between 35 and $29 \mathrm{~d}$ prior to ECD, and were randomly assigned to 1 of 3 treatments before the first milking 28 $\mathrm{d}$ prior to ECD: milking 0 times/d $(\mathbf{0} \times), 1$ time/d $(\mathbf{1} \times)$, or 4 times/d (4×) during the last $28 \mathrm{~d}$ of gestation. Because SCM production with a 56- and 28-d DP was similar in a previous experiment (Rastani et al., 2005), we used a 28-d DP with cows milked $0 \times$ as the control treatment. Cows milked $1 \times$ were milked at approximately $330 \mathrm{~h}$, and cows milked $4 \times$ were milked at approximately 330 , 600,1530 , and $1800 \mathrm{~h}$. If milk production decreased to less than $0.5 \mathrm{~kg} /$ milking or $1 \mathrm{~kg} / \mathrm{d}$, milking ceased; however, teat stimulation continued 1 or 4 times/d according to the treatment assignment. Teat stimulation results in a PRL release similar to milking (Reinhardt and Schams, 1974; Akers and Lefcourt, 1983). After parturition, all cows were milked $2 \times$ at approximately 400 and $1600 \mathrm{~h}$.

All cows were fed the same prepartum diet from $35 \mathrm{~d}$ prior to ECD through parturition and the same postpartum diet from parturition through 70 DIM (Table 1). Cows were fed ad libitum throughout the entire experi- 
Table 2. Nutrient composition of diets

\begin{tabular}{lcc}
\hline Composition $^{1}$ & Prepartum & Postpartum \\
\hline $\mathrm{DM}, \%$ & 45.6 & 53.6 \\
$\mathrm{NE}_{\mathrm{L}}{ }^{2}{ }^{2} \mathrm{Mcal} / \mathrm{kg}$ & 1.58 & 1.69 \\
\cline { 2 - 3 } & & \\
$\mathrm{CP}$ & 13.4 & 16.0 \\
$\mathrm{NDF}$ & 38.2 & 30.5 \\
$\mathrm{ADF}$ & 23.7 & 18.9 \\
$\mathrm{NFC}$ & 38.4 & 40.7 \\
Fatty acids & 3.4 & 6.4 \\
Lignin & 4.6 & 4.2 \\
NDICP & 1.3 & 2.0 \\
ADICP & 0.7 & 0.9 \\
Ash & 6.9 & 7.4 \\
\hline
\end{tabular}

${ }^{1}$ Nonfiber carbohydrates calculated by the difference $100-[(\% \mathrm{NDF}$ $-\% \mathrm{NDICP})+\% \mathrm{CP}+(\% \mathrm{FA}+1)+\%$ ash $] . \mathrm{NDICP}=$ neutral detergent insoluble CP; ADICP = acid detergent insoluble CP.

${ }^{2}$ Net energy for lactation calculated according to NRC (2001), based on actual DMI.

mental period. Diets were fed as a TMR at 1030 and 1630 $\mathrm{h}$, and were formulated to meet nutrient requirements according to the NRC (2001) and predicted DMI. The nutrient composition of the diets is presented in Table 2.

\section{Sampling and Analyses}

Dry matter intake was measured daily. Forages and concentrate samples were obtained weekly and dried for $48 \mathrm{~h}$ to $60^{\circ} \mathrm{C}$ to determine $\mathrm{DM}$; results were used to adjust the forage-to-concentrate ratio. The DM of orts was assumed to be equal to the DM of feed offered. Weekly forage samples were composited monthly for analysis; samples of concentrates were taken monthly for analysis. Samples were dried in a forced-air oven at $60^{\circ} \mathrm{C}$ for $72 \mathrm{~h}$ and ground in a Wiley mill (1-mm screen; Arthur H. Thomas, Philadelphia, PA). Samples were analyzed for CP (method 2001.11; AOAC, 2005) with the following modifications: $0.3 \mathrm{~g}$ of sample was analyzed; $15 \mathrm{~mL}$ of $\mathrm{H}_{2} \mathrm{SO}_{4}, 2.87 \mathrm{~g}$ of $\mathrm{Na}_{2} \mathrm{SO}_{4}$, and $0.13 \mathrm{~g}$ of $\mathrm{CuSO}_{4}$ were added to each tube for digestion; digestion time was $90 \mathrm{~min} ; 40 \mathrm{~mL}$ of water was added to the tubes after digestion; samples underwent steam distillation into a boric acid solution $(4 \% \mathrm{wt} / \mathrm{vol})$ containing $0.20 \%$ methyl red indicator solution and $0.98 \%$ bromocresol green solution; and $0.1 \mathrm{~N} \mathrm{H}_{2} \mathrm{SO}_{4}$ was used to titrate the distillate. Samples were also analyzed for fatty acids (Sukhija and Palmquist, 1988), NDF (Van Soest et al., 1991; Mertens, 1999), ADF, and lignin (Van Soest et al., 1991). Neutral detergent fiber and $\mathrm{ADF}$ residues were analyzed for $\mathrm{CP}$ [neutral detergent insoluble CP (NDICP) and acid detergent insoluble CP (ADICP), respectively; Goering et al., 1972]. The NFC component was calculated as $100-$ $[(\% \mathrm{NDF}-\% \mathrm{NDICP})+(\% \mathrm{FA}+1)+\% \mathrm{CP}+\% \mathrm{ash}]$.

Milk yield was recorded at each milking. Milk samples were obtained from consecutive milkings on $2 \mathrm{~d}$ every week and analyzed for fat, protein, lactose, TS, and SCC using infrared spectrometry (AgSource Milk Analysis Laboratory, Menomonie, WI), and weighted means were computed according to milk production. Body weight was recorded weekly for each cow, and calf BW was measured within $24 \mathrm{~h}$ of calving. The BCS was recorded weekly for each cow by 3 individuals (Wildman et al., 1982).

Blood samples were taken from the coccygeal vein or artery at 300 and $1500 \mathrm{~h}$ on d 30,21 , and 14 prior to ECD, daily from $10 \mathrm{~d}$ prior to ECD to $3 \mathrm{~d}$ postpartum, and on $\mathrm{d} 7$ and 14 postpartum in Vacutainer tubes (Becton Dickinson, Franklin Lakes, NJ) containing sodium heparin. Samples were centrifuged at $915 \times g, 4^{\circ} \mathrm{C}$, for 15 min immediately after sample collection, and plasma was decanted and stored at $-20^{\circ} \mathrm{C}$ until analysis. Plasma PRL was determined in samples obtained from $108 \mathrm{~h}$ prior to calving to $24 \mathrm{~h}$ after calving by RIA, as described by Miller et al. (1999). Mean intra- and interassay coefficients of variation were 8.6 and $6.0 \%$, respectively. Assay sensitivity averaged $1.8 \mathrm{ng} / \mathrm{mL}$.

Total RNA was isolated from lymphocytes, as described by Auchtung et al. (2003). A subset of samples (8 blocks) was analyzed for PRL-R. Expression of PRL$\mathrm{R}$ mRNA was analyzed from samples obtained at $-7,-1$, 1 , and $+7 \mathrm{~d}$ relative to calving. Purification of RNA was conducted using the RNeasy mini kit (Qiagen, Valencia, $\mathrm{CA}$ ), and residual DNA was removed using the DNAfree procedure (Ambion, Austin, TX). Total RNA (2.5 $\mu \mathrm{g})$ was reverse transcribed to $21.5 \mu \mathrm{L}$ of cDNA using the StrataScript First-Strand synthesis system (Stratagene, La Jolla, CA). Real-time PCR was performed using an ABI Prism 7900 HT (Applied Biosystems, Foster City, CA). Primers and probes used for $18 \mathrm{~S}$ were as described by Auchtung et al. (2003), whereas primers and probes to determine total PRL-R (long and short forms combined) were determined using Primer Express (Applied Biosystems). Sequences of the PRL-R probe, forward primer, and reverse primer were 5'-TGGAAGGCAAAATCCCCTA-3', 5'-AGGCCCCTCAGAGCACAAG-3', and 5'TGGGTCCATTGGCCAGAA-3', respectively. The probe was labeled at the $5^{\prime}$-end with the reporter FAM and at the $3^{\prime}$-end with the quencher MGBNFQ. The PCR product length was 60 base pairs. Amplification mixes (20 $\mu \mathrm{L}$ ) contained $10 \mu \mathrm{L}$ of TaqMan universal PCR master mix (Applied Biosystems), $2 \mu \mathrm{L}$ of cDNA, $40 \mathrm{pmol}$ of each primer, and $4 \mathrm{pmol}$ of probe. Reactions were run in triplicate, with PRL-R and 18S run in separate wells. The relative standard curve included 7 dilutions of cDNA derived from heifer mammary tissue, and calculations were as described by Auchtung et al. (2003).

\section{Energy Calculations}

Net energy intake ( $\left.\mathbf{N E}_{\mathbf{I}}\right)$ was determined by multiplying DMI by the calculated energy density of the diet. 
Energy density of the diet was calculated according to NRC (2001) considering a discount factor based on TDN intake above maintenance. Energy required for body maintenance $\left(\mathrm{NE}_{\mathrm{M}}\right)$ was computed using the equation $\mathrm{NE}_{\mathrm{M}}(\mathrm{Mcal} / \mathrm{d})=\mathrm{BW}^{0.75} \times 0.08(\mathrm{NRC}, 2001)$. Pregnancy requirements $\left(\mathbf{N E}_{\mathbf{P}}\right)$ were computed using the equation $\mathrm{NE}_{\mathrm{P}}(\mathrm{Mcal} / \mathrm{d})=\{[(2 \times 0.00159 \times$ days pregnant -0.0353$)$ $\times($ calf BW/45)]/0.14\} $\times 0.64(\mathrm{NRC}, 2001)$. Milk energy was calculated using the equation $\mathrm{NE}_{\mathrm{L}}(\mathrm{Mcal} / \mathrm{d})=\mathrm{MP} \times$ $[(0.0929 \times \mathrm{F})+(0.0563 \times \mathrm{P})+(0.0395 \times \mathrm{L})]$, where $\mathrm{MP}$ is milk production $(\mathrm{kg}), \mathrm{F}$ is fat percentage in the milk, $\mathrm{P}$ is true protein percentage in the milk, and $\mathrm{L}$ is lactose percentage in the milk (NRC, 2001). Estimated EB prepartum was calculated on a weekly basis using the equation $\mathrm{EB}(\mathrm{Mcal} / \mathrm{d})=\mathrm{NE}_{\mathrm{I}}-\left(\mathrm{NE}_{\mathrm{M}}+\mathrm{NE}_{\mathrm{P}}+\mathrm{NE}_{\mathrm{L}}\right)$. Estimated EB postpartum was calculated on a weekly basis using the equation $\mathrm{EB}(\mathrm{Mcal} / \mathrm{d})=\mathrm{NE}_{\mathrm{I}}-\left(\mathrm{NE}_{\mathrm{M}}+\mathrm{NE}_{\mathrm{L}}\right)$.

\section{Statistical Analyses}

Data were analyzed as repeated measures using the mixed models procedure of SAS (SAS Institute, 1999). For all parameters except plasma PRL and PRL-R mRNA expression, pre- and postpartum data were analyzed separately. Three cows (third lactation or greater, one from each treatment) were eliminated from the postpartum analysis; reasons included toxic mastitis (2 cows) and severe enteritis (one cow). All measurements, except PRL and PRL-R, were reduced to weekly means before statistical analysis. For prepartum milk composition, continuously milked treatments $(1 \times$ and $4 \times)$ were compared, because no samples were taken from the other treatment prepartum $(0 \times)$. The statistical model used for analysis of all measurements included treatment effect, parity, time, interaction of parity and treatment, and interaction of treatment and time. The terms specified for the random statement were cow and block nested within parity. The covariance structure used to best fit the model was selected based on Akaike's information criterion (SAS Institute, 1999). All data were covariately adjusted. If treatment was significant in the model, differences between treatments were determined using the PDIFF option (SAS Institute, 1999). If the parity $\times$ treatment interaction was significant in the model, parity $x$ treatment $\times$ week was added to the model. Least squares means and standard errors of the means are reported. Significance was declared at $P<0.05$, and trends were discussed at $P<0.15$.

\section{RESULTS AND DISCUSSION}

\section{DMI}

Mean prepartum DMI tended to be greater for $4 \times$ and $1 \times$ compared with $0 \times(13.3$ and 13.4 vs. $12.3 \mathrm{~kg} / \mathrm{d}$, respec- tively; $P<0.07)$. Prepartum DMI was greater at $3 \mathrm{wk}$ prepartum for $1 \times$ and $4 \times$ relative to $0 \times(P<0.03$; Figure $1)$. Because the cows were all fed the same diet, the increased DMI was likely due to the increased milk production of the cows milked continuously prepartum, and consequently their need to consume more feed to meet their requirements, as previously reported by Rastani et al. (2005). Many researchers have found that DMI is similar for cows milked 2 and 3 times/d postpartum (Pearson et al., 1979; Poole, 1982; DePeters et al., 1985; Barnes et al., 1990), as was the case for the $1 \times$ and $4 \times$ cows prepartum.

Mean postpartum DMI was similar for all treatments and averaged $22.7 \mathrm{~kg} / \mathrm{d}$. In contrast, in a previous study, cows with a 0-d DP that were milked 2 times/d during the last $28 \mathrm{~d}$ of gestation tended to have greater DMI in early lactation compared with cows with a 28-d DP (i.e., cows milked 0 times/d; Rastani et al., 2005).

\section{Milk Production}

Prepartum, $17 \%$ less milk was produced by $1 \times$ than $4 \times$ cows ( 5.9 and $7.1 \mathrm{~kg} / \mathrm{d}$, respectively), but because of high variability among cows, these differences were not statistically significant (Figure 2A). There was a significant treatment $\times$ time interaction, with milk production decreasing for $1 \times$ and $4 \times$ cows over the last $28 \mathrm{~d}$ of gestation, whereas $0 \times$ cows did not produce any milk during this time $(P<0.001$; Figure $2 \mathrm{~A})$. There was also a tendency for a parity $\times$ treatment interaction $(P<0.08$; Figure 2 and Table 3), with continuously milked cows ( $1 \times$ and $4 \times$ ) following their second gestation producing more milk prepartum than did their older counterparts. To our knowledge, this is the first experiment evaluating the use of altering prepartum MF during the last $28 \mathrm{~d}$ of gestation. Increased MF postpartum has resulted in increased milk production (Pearson et al., 1979; Poole, 1982; DePeters et al., 1985; Hillerton et al., 1990; Stelwagen et al., 1994; Bar-Peled et al., 1995; Stelwagen and Knight, 1997; Hale et al., 2003; Dahl et al., 2004b).

There was a significant parity effect, a parity $\times$ treatment interaction $(P<0.05)$, and a tendency for a parity $\times$ treatment $\times$ week interaction for postpartum milk production $(P<0.15$; Figure 2$)$. Postpartum milk production for cows following their second gestation was greater for $0 \times(40.4 \mathrm{~kg} / \mathrm{d})$ compared with $1 \times$ and $4 \times$ cows $(34.1$ and $30.3 \mathrm{~kg} / \mathrm{d}$, respectively; $P<0.05$; Figure $2 \mathrm{~B}$ and Table 3). Differences existed at wk 3 through 6 and wk 8 through 10 postpartum for the $0 \times$ vs. $4 \times$ treatment and at wk 4 through 6,9 , and 10 postpartum for the $0 \times$ vs. $1 \times$ treatment $(P<0.05$; Figure $2 \mathrm{~B})$. Our data support previous research (Annen et al., 2004a; Collier et al., 2004) indicating that a DP is necessary for cows in their second gestation to obtain maximal milk production in 


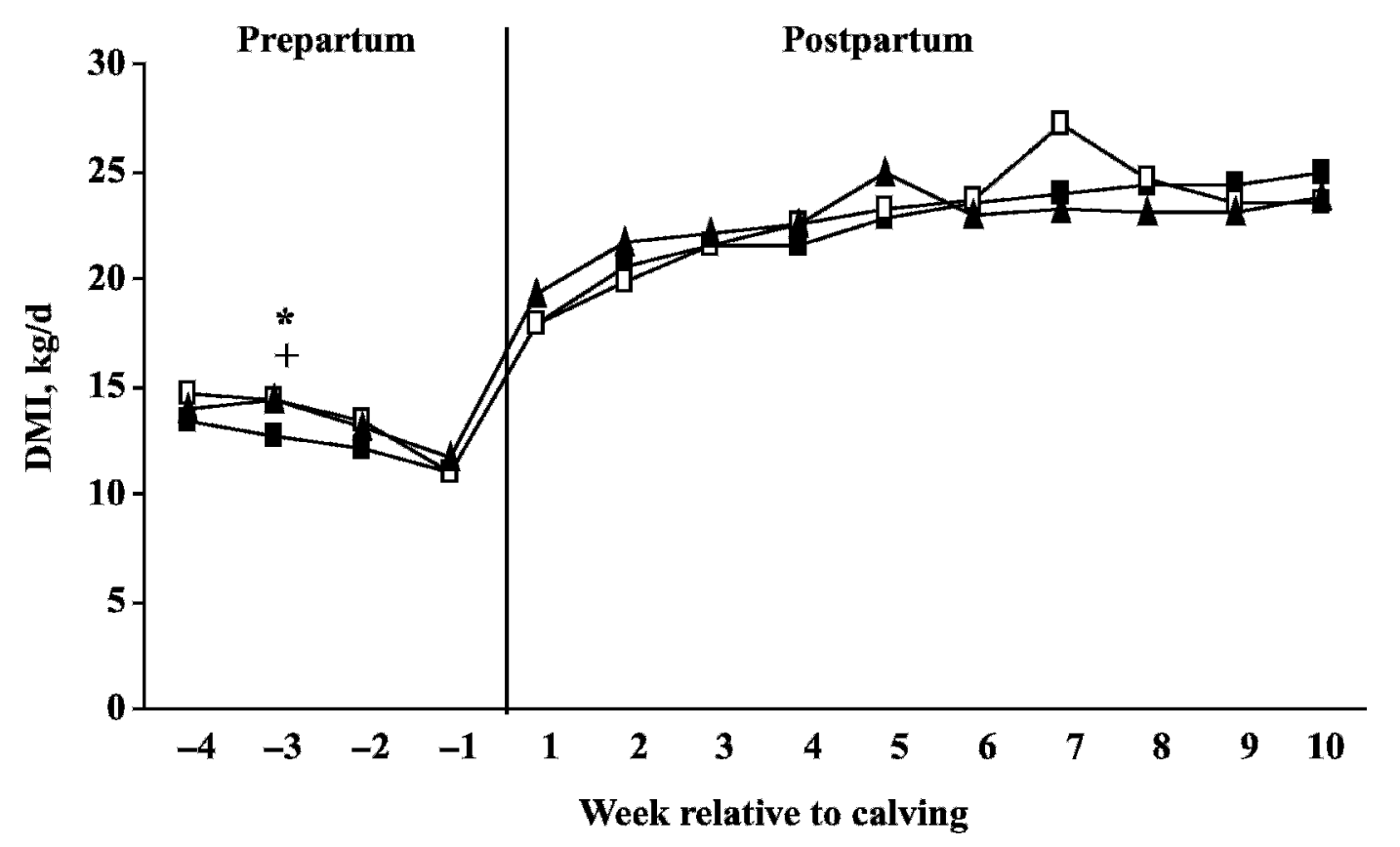

Figure 1. Dry matter intake (kg/d) of cows with different prepartum milking frequencies. Treatments were $0 \times(\mathbf{\square}), 1 \times(\square)$, and $4 \times(\mathbf{\Delta})$ during the last $28 \mathrm{~d}$ of gestation. Values are means $\pm \mathrm{SE}$. Prepartum: treatment, $P<0.10(\mathrm{SE}=0.48)$. Postpartum: $(\mathrm{SE}=0.79)$. Time points with asterisks $(*)$ indicate that DMI differed $(P<0.05)$ between the $0 \times$ and $1 \times$ treatments, and plus signs $(+)$ indicate that DMI differed $(P$ $<0.05$ ) between the $0 \times$ and $4 \times$ treatments.

the subsequent lactation. Prepartum milking of cows in their second gestation, independent of frequency, impedes continued mammary development, whereas older animals no longer have a mammary growth requirement (Collier et al., 2004).

Postpartum milk production for cows in their third or greater lactation was greater for $0 \times$ and $4 \times$ compared with $1 \times(43.3$ and $41.9 \mathrm{~kg} / \mathrm{d}$ vs. $32.7 \mathrm{~kg} / \mathrm{d} ; P<0.01$; Figure $2 \mathrm{C}$ and Table 3). Differences existed at wk 1 through 6 and wk 8 through 10 postpartum for $0 \times$ vs. $1 \times$ treatments and at wk 3 through 5 and wk 9 postpartum for $4 \times$ vs. $1 \times$ treatments $(P<0.05$; Figure $2 \mathrm{C})$. In a previous study, cows that were continuously milked ( 2 times/d in the last $28 \mathrm{~d}$ of gestation) had a $12 \%$ decrease in milk production in the subsequent lactation relative to cows with a 28-d DP (Rastani et al., 2005). Increasing MF to $4 \times$ during the last $28 \mathrm{~d}$ of gestation resulted in similar milk production as cows with a 28 -d DP (i.e., cows on the $0 \times$ treatment).

\section{Milk Composition and SCM Production}

Prepartum, the milk protein percentage differed by treatment $(6.16$, and $4.87 \%$ for the $1 \times$ and $4 \times$ treatments, respectively; $P<0.02$ ). The milk fat percentage prepartum was similar among the continuous milking treatments $(4.75$ and $4.29 \%$ for the $1 \times$ and $4 \times$ treatments, respectively). Cows on the $1 \times$ treatment produced $20 \%$ less SCM than cows on the $4 \times$ treatment (7.7 and 9.7 $\mathrm{kg} / \mathrm{d}$ of SCM, respectively), but that difference was not statistically significant.

Although there was no difference in milk fat percentage postpartum, milk fat yield was greater for $0 \times$ compared with $4 \times(P<0.001)$, with $1 \times$ being intermediate (Table 4). Previous research showed no difference between milk fat percentage for cows with no DP and cows with a 28-d DP (Annen et al., 2004a; Rastani et al., 2005), whereas milk fat yield was greater for cows with a 28-d DP compared with those that were continuously milked (Rastani et al., 2005). Milk protein percentage was greater for $1 \times$ and $4 \times$ cows compared with $0 \times$ cows (3.24 and $3.20 \%$ vs. $2.94 \%$; $P<0.02$; Table 4 ). The $4 \times$ treatment had a reduced milk protein yield compared with the $0 \times$ treatment $(1.16$ vs. $1.27 \mathrm{~kg} / \mathrm{d} ; P<0.03$; Table 4 ), and there was a tendency for $1 \times$ cows to have reduced protein yield compared with $0 \times$ cows (1.12 vs. $1.27 \mathrm{~kg} /$ d; $P<0.12$; Table 4$)$. There was no parity $\times$ treatment interaction for any of the milk composition variables. These data agree with a previous study in which the milk protein percentage was greater and milk protein yield was reduced for cows with no DP relative to cows with a 28-d DP (Rastani et al., 2005). In contrast to our data, Annen et al. (2004a) reported no difference in milk protein percentage between cows with either a 30-d DP or no DP. 

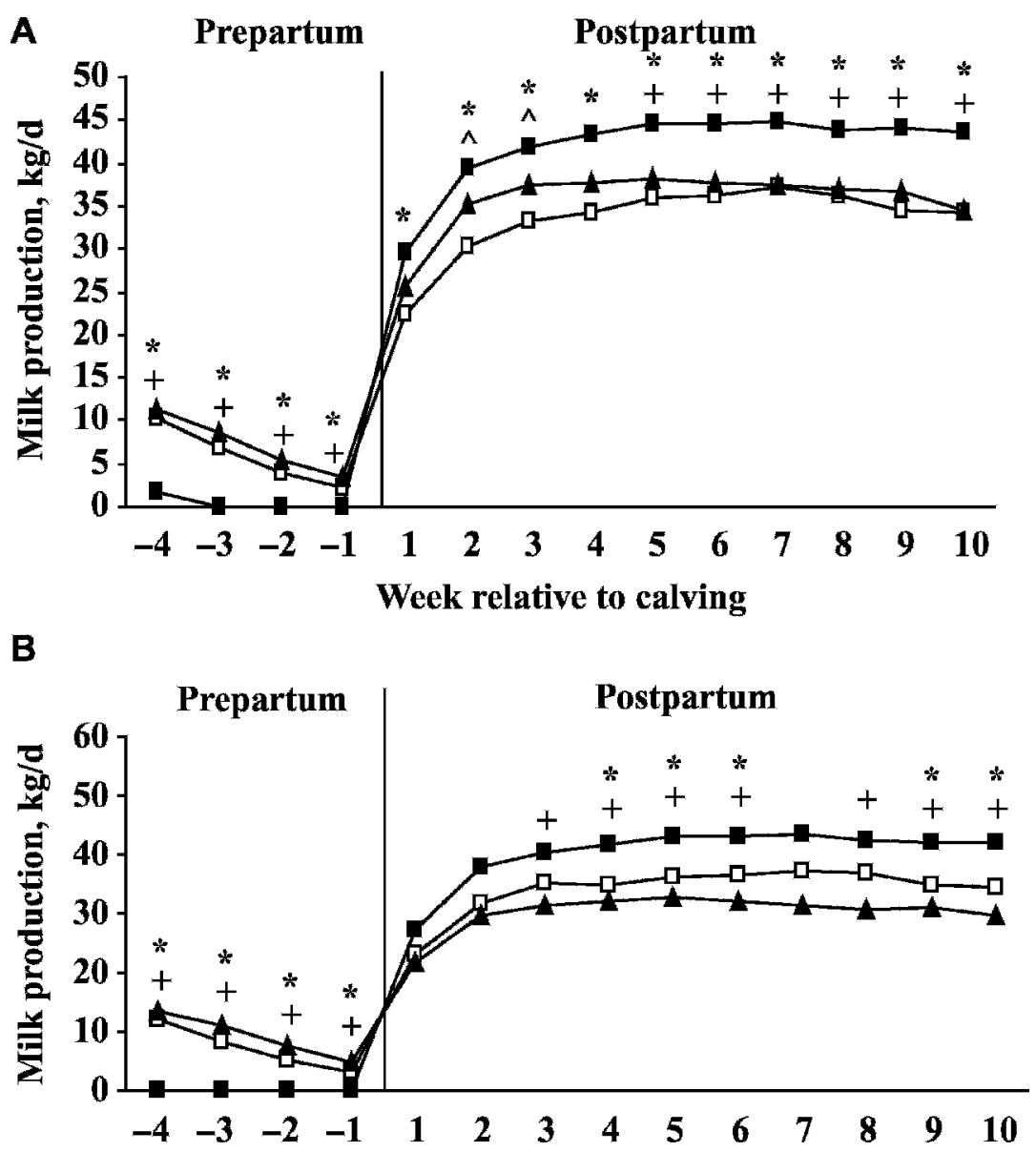

Week relative to calving

C

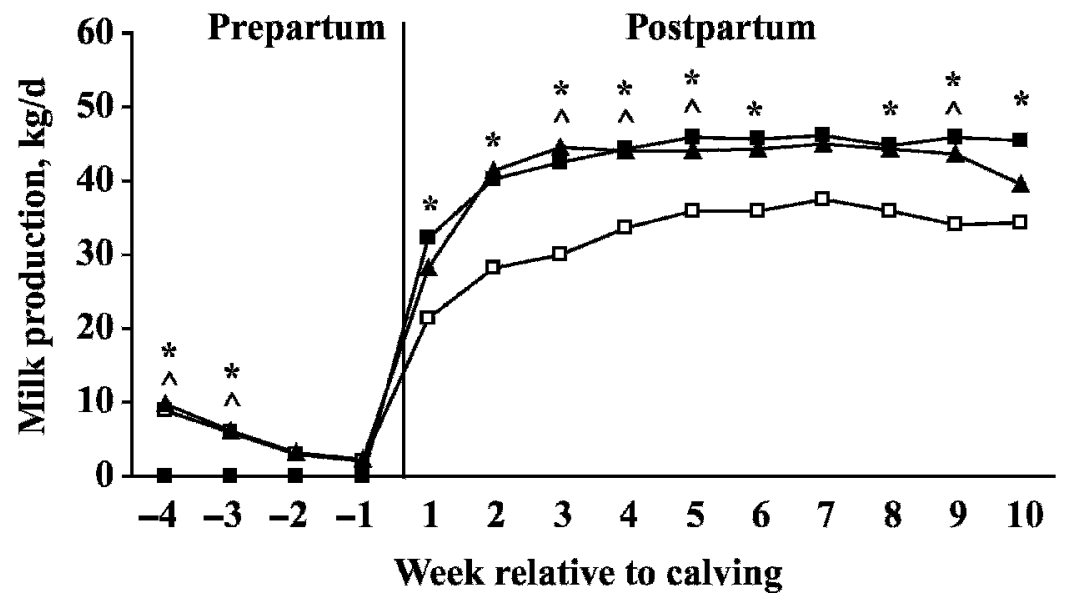

Figure 2. (A) Milk production (kg/d) of all cows with different prepartum milking frequencies. Prepartum: treatment, $P<0.001$; parity $\times$ treatment, $P<0.08$; treatment $\times$ time, $P<0.001$ (SE $=0.88$ ). Postpartum: treatment, $P<0.004$; parity, $P<0.05 ;$ parity $\times$ treatment, $P<$ 0.03; treatment $\times$ time, $P<0.08$ ( $\mathrm{SE}=1.9)$. (B) Milk production $(\mathrm{kg} / \mathrm{d})$ of cows in and following their second gestation with different prepartum milking frequencies. (C) Milk production $(\mathrm{kg} / \mathrm{d})$ of cows in and following their third or greater gestation with different prepartum milking frequencies. Treatments were $0 \times(\square), 1 \times(\square)$, and $4 \times(\boldsymbol{\Delta})$ during the last $28 \mathrm{~d}$ of gestation. Values are means \pm SE. Time points with asterisks (*) indicate that milk production differed $(P<0.05)$ between the $0 \times$ and $1 \times$ treatments, plus signs $(+)$ indicate that milk production differed $(P<0.05)$ between the $0 \times$ and $4 \times$ treatments, and caret signs $(\wedge)$ indicate that milk production differed $(P<0.05)$ between the $1 \times$ and $4 \times$ treatments. 
Table 3. Effect of parity and prepartum milking frequency on pre- and postpartum milk yield

\begin{tabular}{|c|c|c|c|c|}
\hline \multirow[b]{2}{*}{ Item } & \multicolumn{3}{|c|}{ Treatment $^{1}$} & \multirow[b]{2}{*}{$\mathrm{SE}^{2}$} \\
\hline & $0 \times$ & $1 \times$ & $4 \times$ & \\
\hline \multicolumn{5}{|c|}{ Cows following their second gestation } \\
\hline Prepartum 3 milk yield, $\mathrm{kg} / \mathrm{d}$ & $0.0^{\mathrm{a}}$ & $7.1^{\mathrm{b}}$ & $9.0^{\mathrm{b}}$ & 1.0 \\
\hline Postpartum ${ }^{4}$ milk yield, $\mathrm{kg} / \mathrm{d}$ & $40.4^{\mathrm{a}}$ & $34.1^{\mathrm{b}}$ & $30.3^{\mathrm{b}}$ & 1.9 \\
\hline \multicolumn{5}{|c|}{ Cows following their third or greater gestation } \\
\hline Prepartum milk yield, kg/d & $0.0^{\mathrm{a}}$ & $5.0^{\mathrm{b}}$ & $5.5^{\mathrm{b}}$ & 1.4 \\
\hline Postpartum milk yield, $\mathrm{kg} / \mathrm{d}$ & $43.3^{\mathrm{a}}$ & $32.7^{\mathrm{b}}$ & $41.9^{\mathrm{a}}$ & 3.3 \\
\hline \multicolumn{5}{|l|}{${ }^{\mathrm{a}, \mathrm{b}}$ Differ at $P<0.05$} \\
\hline \multicolumn{5}{|c|}{${ }^{1}$ Treatments were milking 0,1 , or 4 times/d prepartum. } \\
\hline \multicolumn{5}{|c|}{${ }^{2}$ Pooled standard error of least squares means. } \\
\hline \multicolumn{5}{|c|}{${ }^{3}$ Prepartum period is -28 to $-1 \mathrm{~d}$ relative to calving. } \\
\hline${ }^{4}$ Postpartum period is +1 to & & & & \\
\hline
\end{tabular}

Postpartum SCM production was greater for $0 \times(40.3$ $\mathrm{kg} / \mathrm{d})$ compared with $1 \times$ and $4 \times$ cows $(40.3 \mathrm{~kg} / \mathrm{d}$ vs. 34.6 and $32.2 \mathrm{~kg} / \mathrm{d} ; P<0.01$; Figure 3). Differences existed at wk 1 through 10 postpartum for the $0 \times$ vs. $1 \times$ treatment; at wk 1 through 4 and at wk 10 postpartum for the $0 \times$ vs. $4 \times$ treatment; and at wk 7 postpartum for the $1 \times$ vs. $4 \times$ treatment $(P<0.05$; Figure 3$)$. These results are due to the greater yield of fat and protein from $0 \times$ cows compared with $1 \times$ and $4 \times$ cows. Postpartum milk composition did not differ by parity, resulting in no parity $\times$ treatment interaction in SCM production.

The SCS was not affected by treatment (Table 4). This is in agreement with previous studies, in which SCS did not differ between cows with a 0-d DP and those with a 28- or 30-d DP (Annen et al., 2004a; Rastani et al., 2005).

\section{PRL Concentration Around Calving}

Prolactin concentration around the time of calving was not affected by treatment (Figure 4). However, there was a treatment $\times$ time interaction in plasma PRL concentra-

Table 4. Effect of prepartum milking frequency on postpartum milk yield, SCM yield, and milk components from 1 to 70 DIM

\begin{tabular}{lcccccc}
\hline & \multicolumn{3}{c}{ Treatment $^{1}$} & & \multicolumn{2}{c}{ Statistic } \\
\cline { 2 - 4 } \cline { 7 - 8 } Item & $0 \times$ & $1 \times$ & $4 \times$ & & $\mathrm{SE}^{2}$ & $P<$ \\
\hline Milk yield, kg/d & $41.8^{\mathrm{a}}$ & $33.4^{\mathrm{b}}$ & $36.1^{\mathrm{b}}$ & & 1.4 & 0.01 \\
SCM yield, kg/d & $40.3^{\mathrm{a}}$ & $34.6^{\mathrm{b}}$ & $32.2^{\mathrm{b}}$ & & 2.1 & 0.01 \\
Fat, \% & 3.49 & 3.54 & 3.33 & & 0.13 & $\mathrm{NS}^{3}$ \\
Fat yield, kg/d & $1.49^{\mathrm{a}}$ & $1.31^{\mathrm{ab}}$ & $1.19^{\mathrm{b}}$ & & 0.08 & 0.005 \\
Protein, \% & $2.94^{\mathrm{a}}$ & $3.24^{\mathrm{b}}$ & $3.20^{\mathrm{b}}$ & & 0.08 & 0.02 \\
Protein yield, kg/d & $1.27^{\mathrm{a}}$ & $1.16^{\mathrm{ab}}$ & $1.12^{\mathrm{b}}$ & & 0.06 & 0.08 \\
SCS $^{4}$ & 3.06 & 3.74 & 3.96 & & 0.46 & $\mathrm{NS}$ \\
\hline
\end{tabular}

${ }^{\mathrm{a}, \mathrm{b}}$ Differ at $P<0.05$.

${ }^{1}$ Treatments were milking 0,1 , or 4 times/d prepartum.

${ }^{2}$ Pooled standard errors of least squares means.

${ }^{3} P>0.15$.

${ }^{4} \mathrm{SCS}=\log 2(\mathrm{SCC} / 100,000)+3$. tions. The difference in plasma PRL concentration was due to differences in the time cows reached the peak of the periparturient PRL surge as well as the time to return to baseline. The plasma PRL concentration peaked at $-12 \mathrm{~h}$ prepartum for $0 \times$ cows, whereas cows that were milked continuously $(1 \times$ and $4 \times)$ peaked at $-24 \mathrm{~h}$ prepartum. No difference was detected in the magnitude of the surge, as measured by the area under the curve from -60 to $24 \mathrm{~h}$ relative to calving, or in PRL-R mRNA expression (data not shown). The earlier and greater PRL surge for cows milked prepartum was reported previously (Malven et al., 1987).

Our initial hypothesis was that increasing MF in continuously milked cows would increase the plasma PRL concentration and up-regulate PRL-R mRNA expression during the time around calving. This hypothesis was based on previous research studies in which the postpartum increase in MF was associated with a greater PRL concentration (Bar-Peled et al., 1995; Dahl et al., 2004a) and greater expression of PRL-R (Dahl et al., 2002). Additionally, prepartum milking of cows was shown to result in an abrupt increase in secretion of PRL into the blood (Malven et al., 1987). Therefore, in the present study, cows milked more frequently in the last $28 \mathrm{~d}$ of gestation were also expected to respond with an increase in the number of mammary cells that differentiate, leading to an increase in milk production.

Our results indicate that increasing the MF caused different responses, depending on the physiological stage of the dairy cow (i.e., prepartum vs. postpartum). Prolactin is not the only hormone regulated by postpartum MF. Also, IGF-I concentrations are increased postpartum in cows milked more frequently, as previously reported (Hale et al., 2003). Thus, one could speculate that IGF-I may be increased with prepartum $\mathrm{MF}$, and the increased IGF-I concentration may act on the mammary gland, resulting in increased milk production. Nevertheless, the observed interaction of treatment $\times$ parity on milk pro- 


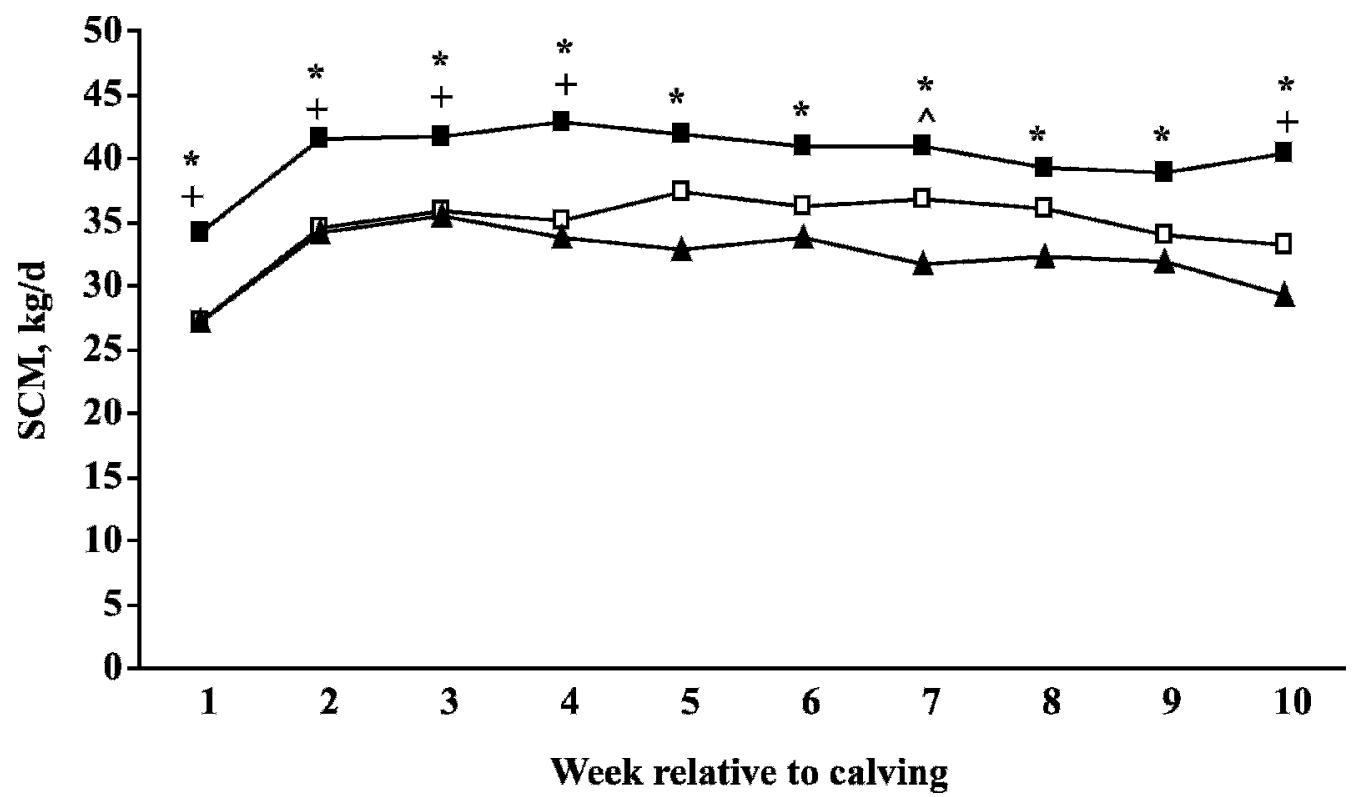

Figure 3. Solids-corrected milk production $(\mathrm{kg} / \mathrm{d})$ of cows with different prepartum milking frequencies. Treatments were $0 \times(\mathbf{\square}), 1 \times(\square)$, and $4 \times(\boldsymbol{\Delta})$ during the last $28 \mathrm{~d}$ of gestation. Values are means \pm SE. Postpartum: treatment, $P<0.01(\mathrm{SE}=2.1)$. Time points with asterisks $(*)$ indicate that SCM differed $(P<0.05)$ between the $0 \times$ and $1 \times$ treatments, plus signs $(+)$ indicate that SCM differed $(P<0.05)$ between the $0 \times$ and $4 \times$ treatments, and caret signs $(\wedge)$ indicate that SCM differed $(P<0.05)$ between the $1 \times$ and $4 \times$ treatments.

duction indicates that if the IGF-I concentration is increased, then it results in a different response based on parity; cows in their third or greater lactation have increased milk production with increased milking fre- quency from $1 \times$ to $4 \times$, whereas cows in their second lactation do not. This interaction between parity and DP length on subsequent milk production was previously reported by Annen et al. (2004a). They observed no loss

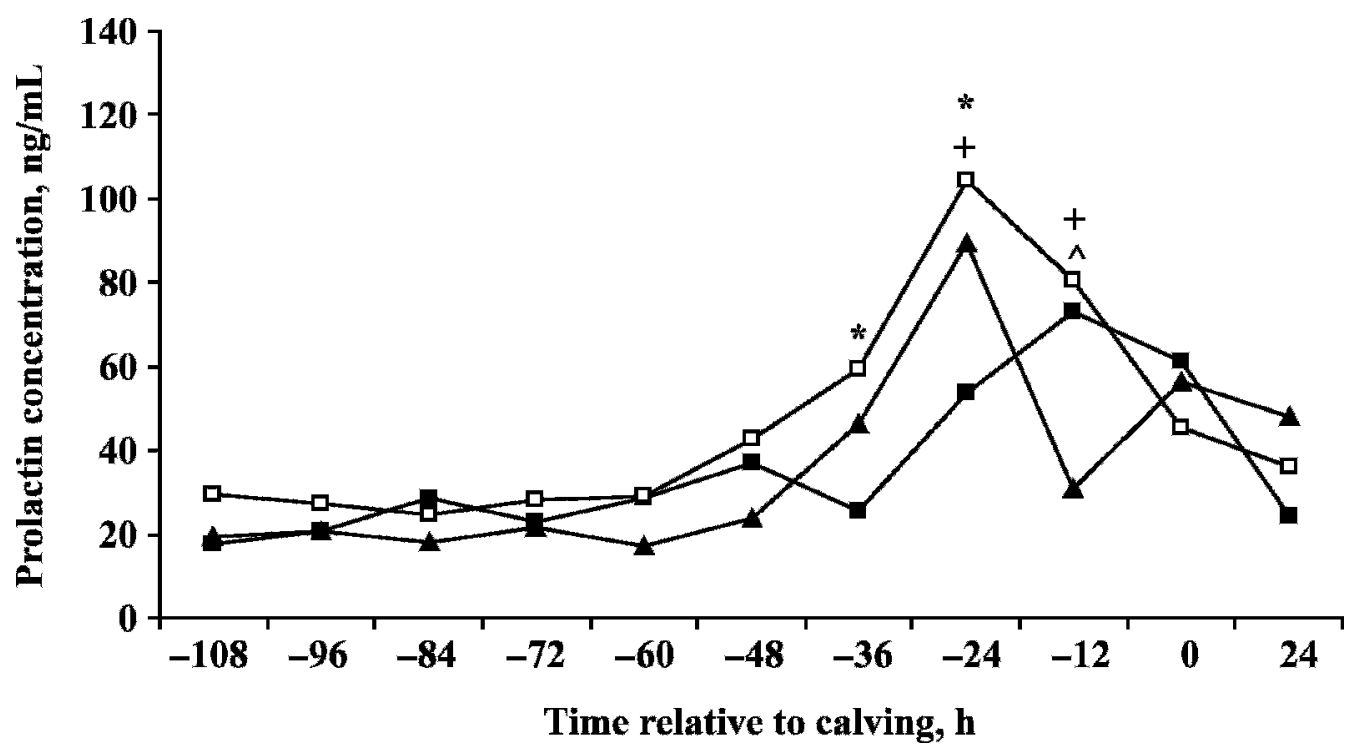

Figure 4. Plasma prolactin concentration $(\mathrm{ng} / \mathrm{mL})$ of cows with different prepartum milking frequencies. Treatments were $0 \times(\boldsymbol{\square}), 1 \times$ $(\square)$, and $4 \times(\boldsymbol{\Delta})$ during the last $28 \mathrm{~d}$ of gestation. Values are means $\pm \mathrm{SE}$. Time, $P<0.001$; treatment $\times$ time, $P<0.02(\mathrm{SE}=5.6)$. Time points with asterisks $\left(^{*}\right)$ indicate that plasma prolactin concentrations differed $(P<0.05)$ between the $0 \times$ and $1 \times$ treatments, plus signs $(+)$ indicate that plasma prolactin concentrations differed $(P<0.05)$ between the $0 \times$ and $4 \times$ treatments, and caret signs $(\wedge)$ indicate that plasma prolactin concentrations differed $(P<0.05)$ between the $1 \times$ and $4 \times$ treatments. 


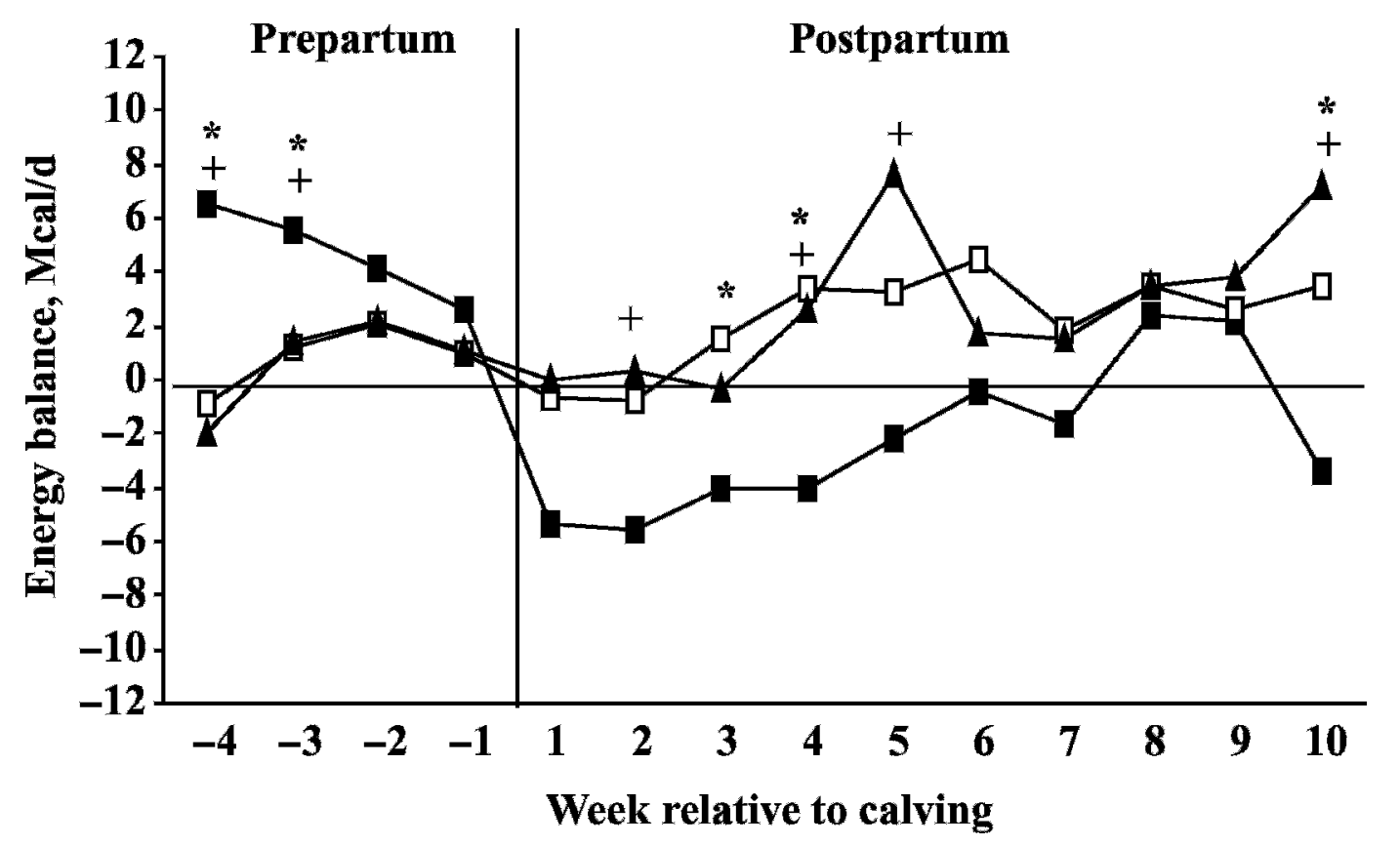

Figure 5. Energy balance (Mcal/d) of cows with different prepartum milking frequencies. Treatments were $0 \times(\boldsymbol{\square}), 1 \times(\square)$, and $4 \times(\mathbf{\Delta})$ during the last $28 \mathrm{~d}$ of gestation. Values are means \pm SE. Prepartum: treatment, $P<0.01$; treatment $\times$ time, $P<0.002$ (SE $=0.97$ ). Postpartum: treatment, $P<0.01$ (SE $=1.4$ ). Time points with asterisks $(*)$ indicate that energy balance differed $(P<0.05)$ between the $0 \times$ and $1 \times$ treatments, and plus signs $(+)$ indicate that energy balance differed $(P<0.05)$ between the $0 \times$ and $4 \times$ treatments.

in milk production by cows that were milked continuously in their third or greater gestation when bST was given either according to label instructions (no bST between parturition and 63 DIM) or continuously (off-label), compared with milk production from cows with a 60$\mathrm{d}$ DP that received bST according to label instructions. However, there was a loss of milk production in cows milked continuously in their second gestation. Because supplemental bST also increases IGF-I concentrations (Peel and Bauman, 1987), it is possible that the same mechanism of action occurred in continuously milked cows in the study by Annen et al. (2004a).

\section{$E B, B W$, and $B C S$}

Mean prepartum EB was greater for $0 \times$ compared with $1 \times$ and $4 \times$ cows $(4.7 \mathrm{Mcal} / \mathrm{d}$ vs. 0.9 and $0.7 \mathrm{Mcal} / \mathrm{d} ; P<$ 0.01 ; Figure 5). Differences existed at wk 4 and 3 prepartum for $0 \times$ compared with $1 \times$ or $4 \times$ cows $(P<0.05$; Figure $5)$. This is in contrast to results from a previous experiment in which cows with a 28-d DP had greater prepartum EB than did cows milked continuously (i.e., no DP, milked 2 times/d) at wk 4 and 3 prepartum (Rastani et al., 2005). In this experiment, the EB difference between $0 \times$ and $1 \times$ or $4 \times$ cows was primarily due to differences in milk production during this time.

Postpartum mean EB was $4.5 \mathrm{Mcal} / \mathrm{d}$ greater for $1 \times$ vs. $0 \times$ cows $(2.3 \mathrm{Mcal} / \mathrm{d}$ vs. $-2.2 \mathrm{Mcal} / \mathrm{d} ; P<0.001)$ and
$5.0 \mathrm{Mcal} / \mathrm{d}$ greater for $4 \times$ vs. $0 \times$ cows $(2.8 \mathrm{Mcal} / \mathrm{d}$ vs. -2.2 $\mathrm{Mcal} / \mathrm{d} ; P<0.001)$. Differences existed during wk 3, 4, and 10 postpartum for $0 \times$ compared with $1 \times$ cows, and during wk 2, 4, 5, and 10 postpartum for $0 \times$ compared with $4 \times$ cows $(P<0.05$; Figure 5$)$. At wk 10, $0 \times$ cows return to negative $\mathrm{EB}$, which was the result of an increase in SCM milk production. Cows milked $0 \times$ had a more severe negative EB postpartum compared with their continuously milked counterparts $(1 \times$ and $4 \times)$. This is in agreement with previous research in which cows with a 28-d DP had a greater negative EB postpartum compared with cows that were milked continuously (Rastani et al., 2005). The more severe negative EB for $0 \times$ cows compared with $1 \times$ and $4 \times$ was due to increased postpartum SCM production.

Despite the differences in prepartum EB (Figure 5), calf BW was not affected by treatment; mean calf BW were between 42.9 and $45.7 \mathrm{~kg}$. The BCS at calving ranged from 3.21 to 3.40 and was not affected by treatment. Postpartum BCS loss and postpartum BW loss were not affected by treatment (data not shown). Previous research has shown that the postpartum BCS loss and BW loss are greater in cows with a 28-d DP compared with a 0 -d DP ( 0.25 units and $29 \mathrm{~kg}$, respectively; Rastani et al., 2005). Based on this, $0 \times$ cows should have lost more BCS units and BW than $1 \times$ or $4 \times$ cows. However, the differences in postpartum EB were not as great in 
this experiment, which may have prevented detection of changes in BW and BCS.

The improvement in postpartum EB for cows milked continuously ( $1 \times$ and $4 \times$ ) during the last $28 \mathrm{~d}$ of gestation is intriguing. Alleviation of negative EB is key to improving the metabolic status of dairy cows. Once cows are in negative $\mathrm{EB}$, their metabolism shifts from anabolism to catabolism. This consequently leads to a predisposition to metabolic disorders, such as hepatic lipidosis and ketosis (Collard et al., 2000; Hayirli and Grummer, 2004).

Improvements in energy status with continuously milked cows ( $1 \times$ and $4 \times$ ) may result in a decrease in postpartum metabolic disorders (Collard et al., 2000; Hayirili and Grummer, 2004). Unfortunately, there were not enough cows in this experiment to determine statistically whether the incidence of metabolic disorders around calving differed because of treatments. The incidences of disorders for cows in the $0 \times, 1 \times$, and $4 \times$ treatments were displaced abomasum $(1 / 15,0 / 15,0 / 15)$, clinical milk fever $(0 / 15,0 / 15,1 / 15)$, ketosis $(0 / 15,2 / 15,0 /$ $15)$, mastitis $(2 / 15,3 / 15,1 / 15)$, metritis $(0 / 15,1 / 15,0 / 15)$, and retained placenta $(0 / 15,1 / 15,2 / 15)$. Definitions of the above disorders are given in LeBlanc et al. (2002).

Energy balance in early lactation has been correlated with resumption of ovarian activity (Butler et al., 1981). In a previous study, continuous milking of cows resulted in a more rapid resumption of ovarian activity, greater first-service conception rate, fewer services per conception, and fewer days open (Gümen et al., 2005). Although EB has a negative relationship with neutrophil function (Stabel et al., 2003), it has a positive relationship with lymphocyte response to mitogens (Ropstad et al., 1989). Goff (2006) hypothesized that negative EB leads to immune suppression in dairy cows. Thus, elimination of the period of negative EB in early lactation through the practice of continuous milking may alleviate immune suppression, enhance reproductive inefficiency, and prevent metabolic disorders in dairy cows. Future experiments using large numbers of animals are needed to test this hypothesis adequately.

\section{CONCLUSIONS}

Increasing prepartum $\mathrm{MF}(0 \times$ vs. $1 \times$ and $4 \times$ ) during the last $28 \mathrm{~d}$ of gestation resulted in a loss of milk production in the subsequent lactation for cows in their second lactation. However, cows in their third or greater lactation had a similar milk yield in the subsequent lactation when they were milked $0 \times$ or $4 \times$ during the last $28 \mathrm{~d}$ of gestation. Data from cows in their third or greater lactation were in agreement with our initial hypothesis that increasing prepartum MF would improve milk production in the subsequent lactation for cows that were denied a DP. However, it did not appear to be mediated through changes in PRL concentration as originally hypothesized. Additionally, cows that were milked continuously $(4 \times$ and $1 \times)$ had a less severe negative EB postpartum compared with a 28-d DP (0x). Future research using large numbers of animals is needed to examine the effects of continuous milking and reduced negative EB on the incidence of metabolic disorders and reproductive performance.

\section{ACKNOWLEDGMENTS}

We would like to thank the John Brandt Memorial Foundation (St. Paul, MN), Hubbard Feeds Inc. (Mankato, MN), MSC Specialty Nutrition (Dundee, IL), Monsanto Co. (St. Louis, MO), Pioneer Hi-Bred International, Inc. (Johnston, IA), Vita Plus Corporation (Madison, WI), and West Central Soy Cooperative (Ralston, IA) for providing financial support for this experiment. The care and feeding of the cows and sampling assistance of Robert Elderbrook, Lew Jones, and Dale Maurer and the skilled laboratory assistance of Christina Baker, Sandra Bertics, Amber Kugel, James Locke, and Robert Rubino are appreciated. We would also like to thank Peter Crump for statistical consultation.

\section{REFERENCES}

Akers, R. M., and A. M. Lefcourt. 1983. Teat stimulation-induced prolactin release in non-pregnant and pregnant Holstein heifers. J. Endocrinol. 96:433-442.

Annen, E. L., R. J. Collier, M. A. McGuire, J. L. Vicini, J. M. Ballam, and M. J. Lormore. 2004a. Effect of modified dry period lengths and bovine somatotropin on yield and composition of milk from dairy cows. J. Dairy Sci. 87:3746-3761.

Annen, E. L., A. C. Fitzgerald, P. C. Gentry, and R. J. Collier. 2004b. Effects of continuous milking and bST on mammary cell proliferation, milk yield, and composition in primiparous cows. J. Dairy Sci. 87(Suppl. 1):132. (Abstr.)

AOAC. 2005. Official Methods of Analysis. AOAC International, Arlington, VA. http://ww.eoma.aoac.org/ Accessed July 20, 2006.

Auchtung, T. L., P. E. Kendall, J. L. Salak-Johnson, T. B. McFadden, and G. E. Dahl. 2003. Photoperiod and bromocriptine treatment effects on expression of prolactin receptor mRNA in bovine liver, mammary gland and peripheral blood lymphocytes. J. Endocrinol. 179:347-356.

Barnes, M. A., R. E. Pearson, and A. J. Lukes-Wilson. 1990. Effects of milking frequency and selection for milk yield on productive efficiency of Holstein cows. J. Dairy Sci. 73:1603-1611.

Bar-Peled, U., E. Maltz, I. Bruckental, A. Folman, Y. Kali, H. Gacitua, A. R. Lehrier, C. H. Knight, B. Robinzon, H. Voet, and H. Tagari. 1995. Relationship between frequent milking or suckling in early lactation and milk production of high producing dairy cows. J. Dairy Sci. 78:2726-2736.

Boutinaud, A., C. Rousseau, D. H. Keisler, and H. Jammes. 2003. Growth hormone and milking frequency act differently on goat mammary gland in late lactation. J. Dairy Sci. 86:509-520.

Butler, W. R., R. W. Everett, and C. E. Coppock. 1981. The relationships between energy balance, milk production and ovulation in postpartum Holstein cows. J. Anim. Sci. 53:742-748.

Collard, B. L., P. J. Boettcher, J. C. M. Dekkers, D. Petitclerc, and L. R. Schaeffer. 2000. Relationships between energy balance and health traits of dairy cattle in early lactation. J. Dairy Sci. 83:2683-2690. 
Collier, R. J., E. L. Annen, and A. C. Fitzgerald. 2004. Prospects for zero days dry. Vet. Clin. North Am. Food Anim. Pract. 20:687-701.

Dahl, G. E., T. L. Auchtung, J. P. Underwood, and J. K. Drackley. 2002. Frequent milking in early lactation that increases milk yield also increases prolactin receptor mRNA expression. J. Dairy Sci. 85(Suppl. 1):53. (Abstr.)

Dahl, G. E., T. L. Auchtung, and E. D. Reid. 2004a. Manipulating milk production in early lactation through photoperiod changes and milking frequency. Vet. Clin. North Am. Food Anim. Pract. 20:675-685.

Dahl, G. E., R. L. Wallace, R. D. Shanks, and D. Lueking. 2004b. Hot topic: Frequent milking in early lactation: Effects on milk yield and udder health. J. Dairy Sci. 87:882-885.

DePeters, E. J., N. E. Smith, and J. Acedo-Rico. 1985. Three or two times daily milking of older cows and first lactation cows for entire lactations. J. Dairy Sci. 68:123-132.

Goering, H. K., C. H. Gordon, R. W. Hemken, D. R. Waldo, P. J. Van Soest, and L. W. Smith. 1972. Analytical estimates of nitrogen digestibility in heat damaged forages. J. Dairy Sci. 55:1275-1280.

Goff, J. P. 2006. Major advances in our understanding of nutritional influences on bovine health. J. Dairy Sci. 89:1292-1301.

Gümen, A., R. R. Rastani, R. R. Grummer, and M. C. Wiltbank. 2005. Reduced dry periods and varying prepartum diets alter postpartum ovulation and reproductive measures. J. Dairy Sci. 88:2401-2411.

Hale, S. A., A. V. Capuco, and R. A. Erdman. 2003. Milk yield and mammary growth effects due to increased milking frequency during early lactation. J. Dairy Sci. 86:2061-2071.

Hayirli, A., and R. R. Grummer. 2004. Factors affecting dry matter intake prepartum in relationship to etiology of peripartum lipidrelated metabolic disorders: A review. Can. J. Anim. Sci. 84:337-347.

Hillerton, J. E., C. H. Knight, A. Turvey, S. D. Wheatley, and C. J. Wilde. 1990. Milk yield and mammary function in dairy cows milked four times daily. J. Dairy Res. 57:285-294.

Kelly, A. L., S. Reid, P. Joyce, W. J. Meaney, and J. Foley. 1998. Effect of decreased milking frequency of cows in late lactation on milk somatic cell count, poly morphonuclear leucocyte numbers, composition and proteolytic activity. J. Dairy Res. 65:365-373.

LeBlanc, S. J., T. F. Duffield, K. E. Leslie, K. G. Bateman, J. TenHag, J. S. Walton, and W. H. Johnson. 2002. The effect of prepartum injection of vitamin E on health of transition dairy cows. J. Dairy Sci. 85:1416-1426.

Malven, P. V., H. H. Head, and R. J. Collier. 1987. Secretion and mammary gland uptake of prolactin in dairy cows during lactogenesis. J. Dairy Sci. 70:2241-2253.

Mertens, D. R. 1999. Variation in aNDF results with modifications of the filter bag method. Technical Session Papers and Committee Reports to the Board and Membership, Topeka, KS. National Forage Testing Association, Omaha, NE.

Miller, A. R. E., E. P. Stanisiewski, R. A. Erdman, L. W. Douglass, and G. E. Dahl. 1999. Effects of long daily photoperiod and bovine somatotropin (Trobest ${ }^{\circledR}$ ) on milk yield in cows. J. Dairy Sci. 82:1716-1722.

NRC. 2001. Nutrient Requirements of Dairy Cattle. 7th ed. National Academy Press, Washington, DC.

Pearson, R. E., L. A. Fulton, P. D. Thompson, and J. W. Smith. 1979. Three times a day milking during the first half of lactation. J. Dairy Sci. 62:1941-1950.

Peel, C. J., and D. E. Bauman. 1987. Somatotropin and lactation. J. Dairy Sci. 70:474-486.
Politis, I., E. Block, and J. D. Turner. 1990. Effect of somatotropin on the plasminogen and plasmin system in the mammary gland: Proposed mechanism of action for somatotropin on the mammary gland. J. Dairy Sci. 73:1494-1499.

Politis, I., E. Lachance, E. Block, and J. D. Turner. 1989. Plasmin and plasminogen in bovine milk: A relationship with involution? J. Dairy Sci. 72:900-906.

Poole, D. A. 1982. The effects of milking cows three times daily. Anim. Prod. 34:197-201.

Rastani, R. R., R. R. Grummer, S. J. Bertics, A. Gümen, M. C. Wiltbank, D. G. Mashek, and M. C. Schwab. 2005. Reducing dry period length to simplify feeding transition cows: Milk production, energy balance, and metabolic profiles. J. Dairy Sci. 88:1004-1014.

Reinhardt, V., and D. Schams. 1974. Analysis of teat stimulation as specific stimulus for prolactin release in cattle. Neuroendocrinology 14:289-296.

Remond, B., A. Ollier, and G. Miranda. 1992. Milking of cows in late pregnancy: Milk production during this period and during the succeeding lactation. J. Dairy Res. 59:233-241.

Remond, B., J. Rouel, N. Pinson, and S. Jabet. 1997. An attempt to omit the dry period over consecutive lactations in dairy cows. Ann. Zootech. 46:399-408.

Ropstad, E., H. J. Larsen, and A. O. Refsdal. 1989. Immune function in dairy cows related to energy balance and metabolic status in early lactation. Acta Vet. Scand. 30:209-219.

SAS Institute. 1999. User's Guide: Statistics. Version 8 Edition. SAS Institute, Cary, NC.

Smith, A., J. V. Wheelock, and F. H. Dodd. 1967. The effect of milking throughout pregnancy on milk secretion in the succeeding lactation. J. Dairy Res. 34:145-150.

Sorensen, A., D. D. Muir, and C. H. Knight. 2001. Thrice-daily milking throughout lactation maintains epithelial integrity and thereby improves milk protein quality. J. Dairy Res. 68:15-25.

Stabel, J. R., J. P. Goff, and K. Kimura. 2003. Effects of supplemental energy on metabolic and immune measurements in periparturient dairy cows with Johne's disease. J. Dairy Sci. 86:3527-3535.

Stelwagen, K., S. R. Davis, V. C. Farr, and S. J. Eichler. 1994. Effect of once daily milking and concurrent somatotropin on mammary tight junction permeability and yield of cows. J. Dairy Sci. 77:2994-3001.

Stelwagen, K., and C. H. Knight. 1997. Effect of unilateral once or twice daily milking of cows on milk yield and udder characteristics in early and late lactation. J. Dairy Res. 64:487-494.

Swanson, E. W. 1965. Comparing continuous milking with sixty-day dry periods in successive lactations. J. Dairy Sci. 48:1205-1209.

Sukhija, P. S., and D. L. Palmquist. 1988. Rapid method for determination of total fatty acid content and composition of feedstuffs and feces. J. Agric. Food Chem. 36:1202-1206.

Van Soest, P. J., J. B. Robertson, and B. A. Lew. 1991. Methods for dietary fiber, neutral detergent fiber, and nonstarch polysaccharides in relation to animal nutrition. J. Dairy Sci. 74:3583-3597.

Wilde, C. J., A. J. Henderson, C. H. Knight, D. R. Blatchford, A. Faulkner, and R. G. Vernon. 1987. Effects of long term thrice-daily milking on mammary enzyme activity, cell population and milk yield in the goat. J. Anim. Sci. 64:533-539.

Wildman, E. E., G. M. Jones, P. E. Wagner, R. L. Boman, H. F. Troutt, Jr., and T. N. Lesch. 1982. A dairy cow body condition scoring system and its relation to selected production characteristics. J. Dairy Sci. 65:495-501. 